\title{
We Don't Need another Hero: Queering Representations of Dissident Sexualities from the Recent Argentine Past ${ }^{*}$
}

\author{
Moira Pérez \\ perez.moira@gmail.com \\ Scholar and Researcher \\ Universidad de Buenos Aires \\ Universidad Nacional de Lomas de Zamora \\ Avenida Las Heras $3931,8^{\circ} \mathrm{A}$ \\ C1425ATD - Buenos Aires \\ Argentina
}

\begin{abstract}
The aim of this paper is to present a view of the contributions that literary representations can offer to our understanding of the past, particularly in relation to subjects who occupied marginal positions in the time and place under study. Using as an example the case of queer subjects during the past military régime in Argentina (1976-1983), I will consider how their narratives are affected by some of the more recurrent tropes in historiographical representations, and how their approach through literature can serve as an invitation to multiply the potential of (his)stories about our past. To achieve this purpose, the paper starts by reviewing the notions of "normal" or "professional" historiography, following contemporary theorists and philosophers of history. Then it moves on to incorporate some of the contributions that a queer perspective can offer to historiography, focusing particularly on the notions of agency, spatiality, temporality, identities and methodology. As case studies or examples, I will refer mainly to three (hi)stories that illustrate the lives of queer subjects during that period: Mi recordatorio (My Remembrance), by Malva (2011), El diablo en el pelo (The Devil in the Hair) (2003), by Roberto Echavarren, and La brasa en la mano (Embers in the Hand) (1983), by Oscar Hermes Villordo. By way of conclusion, I will defend not a replacement or disdain of "normal" historiography, but the multiplication, broadening and dislocation of sources and resources for the representation of the past: various subjects, forms, contents and dynamics between one and the other, for the queering of historiography, and of history itself.
\end{abstract}

\section{Keywords}

Literature; Queer studies; Argentina.

Received in: 8/9/2014

Approved in: 10/24/2014

${ }^{*}$ A version of this work was read at the Queering Paradigms IV Conference, Rio de Janeiro, Brasil, July 2012. 
In 2011, an Argentine activist named Valeria Ramírez made the news (RAMÍREZ 2011) as she testified for the first time that she had been held in a clandestine detention camp during the past military régime in Argentina (19761983). Ramírez, who identifies as a travesti, ${ }^{1}$ had started walking the streets as a sex worker at 22, during the military government. Both before and after the coup - and even in our days - travestis were and are detained, tortured and raped in police stations and prisons throughout Argentina. This is why Valeria, just like many other travestis, along with sex workers and queer folk in general, never thought of themselves as victims of what has come to be known as "State terrorism" ("terrorismo de Estado"). In their personal chronology, the coup in itself did not signify much.

Today, Ramírez and others are starting to interpret their past differently, as a unique experience at the crossroads of gender identity, class identity, and activism - "we had our own type of activism", she says, referring to the travesti corporeality and their group solidarity.

However, this shift of interpretation took longer to be realized in terms of local law and historiography: we can look in vain for traces of these queer subjects in the early trials against the perpetrators, or in canonic approaches to those times (such as remembrance days, mass-media documentaries or high school History resources). Though there has been research done on the matter, such as Osvaldo Bazán's Historia de la homosexualidad en la Argentina (BAZÁN 2004) and Flavio Rapisardi and Alejandro Modarelli's Fiestas, baños

204 y exilios: los gays porteños en la última dictadura (RAPISARDI; MODARELLI 2001), it is born from within activism or cultural studies rather than as a part of mainstream "professional historiography", which is the field I will analyze in this paper. Additionally, both quoted works are produced by and focused on gay male subjects (in the first case, extended to "homosexuality"), leaving other types of dissident sexualities and genders beyond their explicit scope.

Still, there are traces of experiences such as Ramírez', offered not by "professional historiography", but by other kinds of materials. In the same year of the article on Valeria Ramírez, a book (MALVA 2011) was published in which another travesti, called Malva, offered her memoirs, with details of the astounding life she led since her childhood in Chile up to the return of democracy in Argentina in the 1980s. In this work, presented as an autobiography, Malva goes through the details of the experience of being queer during the governments of Juan Domingo Perón (1946-1955 and 1973-1974) and the successive military régimes, including many stays in prison, police raids and fear among the queer community surrounding her. Again, the violence experienced during democratically elected governments and then during the military régime was not significantly different, and - as in other books I will be considering here -

\footnotetext{
${ }^{1}$ The term "travesti" is not an exact equivalent to the English "transvestite", which is why I have chosen not to translate it. In Argentina, travesti is a gender identity of its own, which is neither equivalent to "woman" nor to "trans". It usually describes people who choose to present themselves in a name and clothing that will be read as female, but who do not identify themselves as "women" nor wish to undergo full "reassignment" surgery. Sadly, the history and present of travestis in Argentina is strongly tied to poverty, internal migration, prostitution and State violence.
} 
the fate of queers depended more on the officer's mood than on the structural conditions of the State.

Malva's book offers a new, alternative look on an age in our country that has been very much studied by historians, both in Argentina and abroad. However, works such as this one hardly comply with the norms of "professional historiography" (and, incidentally, probably do not want to be admitted either).

In this paper, I intend to address the limits of what we call "professional historiography" or "normal historiography", and the possibilities offered by alternative representations of the past, particularly in relation to queer subjects. Unlike other available approaches, in my case I understand "queer subjects" as people usually taken as privileged examples by queer studies, even though perhaps they do not identify themselves as such due to various reasons, including geography, chronology, politics and class. It is vital to establish this difference, since in my work "queer" is presented as a political and epistemological category, and not as an ontological one.

In order to achieve my purpose, the paper starts by reviewing the notions of "normal" or "professional" historiography, following contemporary theorists and philosophers of history. Then it moves on to incorporate some of the contributions that a queer perspective can offer to historiography, focusing particularly on some aspects of the past that are usually not addressed by its professional counterpart. As a result, the analysis will provide a view of the unique contributions that non-professional representations can offer to our understanding of the past, particularly in relation to agency, spatiality, temporality and the interaction of identities.

As case studies or examples, I will mainly refer to three stories - or histories - that illustrate the lives of queer subjects during the second half of the $20^{\text {th }}$ century in our region. They are Mi recordatorio (My Remembrance), the memoirs written by Malva (2011) mentioned above, El diablo en el pelo (The Devil in the Hair) (2003), a novel by Uruguayan writer Roberto Echavarren (1944-), and La brasa en la mano (Embers in the Hand) (1983), one of the first novels in Argentina fully and explicitly dedicated to homosexuality, by Oscar Hermes Villordo (1928-1994). However, it is important to note that these suggestions can also be applied to representations that are often cast further away from historiography - films, theatre, performance art -, as they all open up new possibilities for our ways of approaching the past.

\section{"Normal Historiography" and the Professional Crafting of the Past}

In order to present a queer perspective as an alternative approach of history, it is necessary to begin by considering what we have called "normal historiography". What is "normal" or "professional" historiography? Does it actually exist? Is it really so different from its alternatives?

"Normal History" or "Normal Historiography" is a name some history theorists have given to what is agreed as a standard historiographical practice in our times. The expression is taken from Thomas Kuhn's philosophy of science, according to which there is a stage of science called "normal science" in which 
the scientific community agrees upon a number of professional standards, objects of interest, methodologies, basic knowledge, and so on (KUHN 1970). ${ }^{2}$ Needless to say, there is no such thing as a "perfect" "normal" historian (just like there is no "perfect" "normal" scientist), but, rather, a number of tendencies in the educational and research institutions that guide the practice. Among other things, these standards have the function of determining what remains within the field of historiography and what does not. Each age has its own idea of what "normal historiography" is - a classification which, like all classifications, works among other things through exclusion. In this paper, one of my aims is to expose what is being disabled when certain representations of the past are excluded from the field of historiography.

Robert Berkhofer is one of the authors who uses the category "normal history", and characterizes it in his book Beyond the Great Story (1995). This piece comes at a time when the discipline had already been questioned from several fronts, which objected mainly to that "Great Story" Berkhofer refers to in his title. In the author's view, "normal history" works on the assumption that "historians' works are accurate representations of an actual past", and that this is possible because written history is "a transparent medium between the past and the reader's mind" (BERKHOFER 1995, p. 28). In a similar vein, Frank Ankersmit (1986, p. 19) has noted that what the linguistic turn came to question was the idea of a historical text that is transparent in relation to both the historical - past - reality, and the historian's interests or judgment of what is

206 worth including in his narration. This alleged transparency determines the main focus of the professional training in the trade: how to approach the evidence. In this sense, "normal historical practice depends on the use of professionally accepted methods for obtaining facts about the past from surviving evidence, or sources" (BERKHOFER 1995, p. 28). However, there is another vital step that is rarely stated explicitly: "combining those facts into a coherent narrative or other form of synthesis" - that is, the process by which "the normal historian creates generalizations that are assembled into a synthesis" (BERKHOFER 1995, p. 28). Reflecting on why this step is not explicitly analyzed as frequently as the previous one can be an interesting key to understanding the mechanisms and investments behind "normal historiography".

\section{"Gay \& Lesbian" Historiography: Seeking a Place in History}

It is widely acknowledged that what today functions as "normal historiography" has done a good service to gay-lesbian communities. ${ }^{3}$ A number of versions of "normal historiography" from the late $20^{\text {th }}$ century have helped

\footnotetext{
${ }^{2}$ For Kuhn, "'normal science' means research firmly based upon one or more past scientific achievements, achievements that some particular scientific community acknowledges for a time as supplying the foundation for its further practice". For normal science to take place, there must be a commitment of specialists "to the same rules and standards for scientific practice", "and the apparent consensus it produces". Books aligned with "normal science", particularly those assigned in courses and specialized training, "define the legitimate problems and methods of a research field" (KUHN 1970, p. 10).

3 The use of "Gay \& Lesbian" instead of "LGBT" or longer acronyms is intentional in this case, given that the histories presented here were by and large written by and directed at gay (cis) men and lesbian (cis) women, rarely involving other dissident sexual or gender identities in their elaboration or their analysis.
} 
understand the different ways in which gender and sexuality have developed throughout history. The works of John D'Emilio (D'EMILIO 1983), Jeffrey Weeks (WEEKS 1977), Martha Vicinus and others, including the oft-cited anthology Hidden from History, Reclaiming the Gay \& Lesbian Past (DUBERMAN 1989), have brought to light many details of the history of dissident genders and sexualities. At that stage, most works aimed at broadening the scope of historiography, incorporating characters and subjects that had thus far not been included, and also aspects of life, such as sexual and gender presentations, which were not considered relevant factors by many historiography researchers.

The developments of alternative historiographies, however, including the contributions of Queer Theory, allow us to look critically at these narratives of the past. These perspectives have come to notice that it is not sufficient for a field such as historiography to merely add new objects of inquiry - for example, broadening the range of subjects in a given story to include samesex desire and gender dissidents. In order to queer history and historiography, we need to queer the way in which we make historiography: its assumptions, its methods, its modes of presentation and the narratives which support it and make it possible. As Joan Scott (1991) has noticed, historiography tends to be foundationalist, i.e., "its explanations seem to be unthinkable if they do not take for granted some primary premises" (SCOTT 1991, p. 780), and what we usually witness as radical changes are actually just a switch from one foundation (for example, "objectivity") to another (in her example, "experience"). It is these foundations that we need to analyze, if we want to think of queer ways of making historiography.

This is the kind of work undertaken by Henry Abelove in an early article (ABELOVE 1995), which appeared in a special issue of Radical History Review dedicated to the rise of queer history and historiography. Taking as a case study his undergraduate students at university, the author compares the readers and production of historiography in the times of "Gay \& Lesbian History" (which, as seen above, was guided by the premises of what we called "normal historiography"), and in the present - that is, in the 1990s - as a new "queer historiography" began to emerge. Abelove considers that the arrival of Queer Theory in the academy brought a radical shift in the way historiography is made, read and appraised: the change from "gay" to "queer" is, according to the author, "a very fundamental change indeed, a change that amounts to a shift in sensibility, style, tone, values, and commitments. For one thing, this change has apparently produced a partly new way of reading and thinking history" (ABELOVE 1995, p. 44). In his work, he sets out to describe the students' reactions to the material he assigns in his courses, comparing the reception found in the nineties, when students were already identifying as "queer", with the one in previous decades, when students identified as "gay" and "lesbian". Far from being a liability, I consider the early date of this study as an asset, since it allows us to detect the shift in paradigm at the very moment in which it was taking place.

In general terms, "Gay \& Lesbian History" can be seen as the attempt to include in available historical narrations the experience and presence of gender 
and sexual dissidents of various sorts. The methodology and techniques remain the same as those of what we called "normal historiography", and with them also the presuppositions that support historiographical work: for example, that "the truthfulness or validity of a history can be tested by reference to the actual past itself" (BERKHOFER 1995, p. 29). The historian's work is to create generalizations that will allow us to grasp some of the "plenitude" in the past, usually by inserting the subject of inquiry in its context. On occasions, the historian also tries to track present identities and behaviors back to their origins, for example by drawing a line of continuity from what we see today as masculine homosexual behavior, back to man-to-man sexual relationships in ancient times (a whole sub-genre in the historiographical field).

Before moving on to the queering of historiography in our literary examples, I would like to go through some important traits of "Gay \& Lesbian History", following Abelove's experiment and what his students noticed in the older material he assigned. By doing so, we will be able to point out a number of traits that can convey more perspective to the achievements of the queerization of historiography in our narratives of the past.

Abelove considers that one of the main differences between the queer-identified generation of readers in the 1990s and his own is that the former tends to see previous historical narratives as too strongly based on the trope of marginalization. The point here is not so much that the stories retrieved in "Gay \& Lesbian History" are about people who lived in the margins (among 208 other things, due to their sexual and/or gender identities), but that their oppression, their suffering and the violence exerted upon them is the focus of the narratives, and consequently one of the most common criteria when choosing which ("normal") stories to tell. "Normal historiography" also appears in the way in which these narratives regard agency: its subjects are on most occasions individuals capable of free, sound decisions which they can carry forward, and, as a result, on many occasions - these are the tales of progress - gain coherence and "authenticity". For example, a given gay-lesbian community struggles against marginalization and by means of the thorough, coherent decisions of their leaders achieves a certain degree of freedom, thus being able to exercise its "authentic" sexuality with no significant limitations.

Another point that emerges in Abelove's paper, and one particularly important for the case I have chosen to examine here (a specific time in the Argentine political context), is the fact that traditional "Gay \& Lesbian Histories" are usually framed in a nation-State context. Almost all of the historiographies produced in this manner refer to a specific country and seek, as we have seen, to include these allegedly "new" subjects in the broader history of that nation. ${ }^{4}$

\footnotetext{
${ }^{4}$ In this regard, it is worth noting that the "nation-State" theme also appears in Vito Russo's classic, The Celluloid Closet (RUSSO 1987), where he explains that representations in cinema of gay and lesbian subjects served the purpose of giving shape to a model of nation - a model in which, of course, gay, lesbian and otherwise queer subjects were not included. It is precisely due to the awareness of this kind of exclusions that queer subjects in the 1990 s rejected the idea of building historiography in terms of nation-States.
} 
Finally, "Gay \& Lesbian History" is also aligned with what I called "normal historiography" in terms of the sources and methodologies it uses to produce narratives of the past. This is, according to some theorists (e.g. JENKINS 1997), the last realm of traditional historiography to be lost to postmodernism: the methodological presuppositions of the historian's profession. Far from them belonging to a separate sphere, independent of the contents privileged by historiography, these factors are closely related to the items mentioned above (which subjects, tropes and framings are chosen when portraying the past). The sources and methodologies adopted by historiography and the realms it takes as objects of inquiry depend on one another and, in this sense, each choice made by historians in one sphere prefigures what can be done in the other.

\section{Queering History}

As a counterpart to these criticisms, what could queers expect from - and produce in - historiography in the way of an alternative to this? What contribution can a queer perspective make to a critical reappraisal of historiographical research? Which were and are the queer alternatives to these "Gay \& Lesbian" approaches?

As I mentioned above, early "Gay \& Lesbian History" (and its current representatives) had as its task to "bring light" to the experience of gender and sexual dissidents of the past, following the idea of a history that had to be "completed". However, there are a number of questions that this enterprise rarely asked. As Joan Scott argues in her brilliant paper "The evidence of experience":

The project of making experience visible precludes critical examination of the workings of the ideological system itself, its categories of representation (homosexual/ heterosexual, man/woman, black/white as fixed immutable identities), its premises about what these categories mean and how they operate, and of its notions of subjects, origins and cause (SCOTT 1991, p. 778).

Subsequently, Scott adds that "making visible the experience of a different group exposes the existence of repressive mechanisms but not their inner workings or logics; we know that difference exists, but we don't understand it as relationally constituted" (SCOTT 1991, p. 779). Earlier on, Gayatri Spivak had already suggested that literature and literary theory can go beyond this limitation faced by historiography and enter more deeply into the deconstructive task:

A historian confronts a text of counterinsurgency or gendering where the subaltern has been represented. He unravels the text to assign a new subject-position to the subaltern, gendered or otherwise. A teacher of literature confronts a sympathetic text where the gendered subaltern has been represented. She unravels the text to make visible the assignment of subject-positions (SPIVAK 1987, p. 241). 
Despite early warnings such as these, "normal" historiographers have been by and large reluctant to work side by side with other kinds of representations, perhaps because this sort of statements tends to be read as a degradation of historiographical work (WHITE 2011), or as a need to choose one above the other. Far from that, once we understand that each approach has its own strengths and can contribute with its own, unique perspectives, then we can work towards the inclusion of historiographical, literary and other perspectives in our quest to find new, richer interpretations of the past.

The case of Valeria Ramírez and the absence of travestis in the "official" or mainstream accounts of historiography on Argentina can serve as a good example of this. While historiography was written without questioning certain identities and categories (for example, what constituted a political act and political resistance), the lives of gender dissidents could be overlooked in an account of state terrorism. However, once we start to question our presuppositions on gender, politics and embodiment, we may begin to read differently the experiences of these people, and to blend them into our accounts of the past. In the meantime, "Gay \& Lesbian History" will continue "filling the gaps", most likely leaving the presuppositions unquestioned, but providing research on queer folks that were politically active in "traditional" ways, and therefore should be included in "normal" historical accounts of our past.

Just like many issues raised by Abelove's students can be easily related to what we have called "normal" historiography, their preferences echo strongly in 210 what queer histories have been producing since then. In what follows, I refer to some of these traits by making use of the chosen literary works as examples of the potential that the field offers for the portrayal of queer (hi)stories.

As we saw above, those "new" queer generations, albeit acknowledging that throughout history queers have had to endure many struggles, still preferred to emphasize other aspects of the past, particularly the ones in which queers appeared in a more positive, optimistic light. On a first approach, this could seem naive and even self-centered: it is not the same to live as (a certain kind of) queer in the nineties than it was in the fifties or sixties, and this difference probably goes a long way in explaining the optimism of the former and the dark, even tragic perspectives of the latter. However, one could also read this assessment by young queers in the light of an empowering approach of historiography, according to which it can be thought as performative as well: our ways of seeing the past are crafted by looking towards the building of a brighter future. This, among other things, can explain why these queer students found such stories of marginalization neither false nor altogether objectionable, but rather just not challenging, or even simply uninteresting. ${ }^{5}$

\footnotetext{
${ }^{5}$ Since the time of Abelove's paper to our days, there has been a deep debate in the field of queer studies regarding optimism, pride and joy within the queer community. Some works, such as those of Heather Love and Jack Halberstam, have even presented their contributions specifically in relation to the representation of the past. Unfortunately, this debate exceeds the scope of this paper; for further reading, see LOVE 2009 and HALBERSTAM 2011.
} 
The literary examples chosen for this paper offer notable results in this respect. Representations of homosexuality (and dissident genders and sexualities in general) in Argentine literature tend to be strongly marked by negative tropes, such as violence, punishment, suffering - and marginalization, just like Abelove's students noticed in the histories they read. In a historical context of repression and institutional violence, it is hard to imagine tales of queer pasts presented in a positive, lighthearted spirit. The narratives of Mi recordatorio, El diablo en el pelo, and La brasa en la mano are very much marked by these negative tropes: they revolve mainly around situations of fear of security forces, concealing visible markers of their sexuality, the recourse to prostitution not as a choice but as survival, and so on.

However, as we look closer, there are other things that become visible. The characters in these stories, especially in Mi recordatorio and in La brasa en la mano, have come to conform queer communities, new families in which they can act freely, protect each other and forget the merciless outside world for a while. Here, queers rebuild their families, tied not by blood but by love and companionship. These representations are given to us not through "normal historiography", for which the relevant data is usually the number of homosexuals imprisoned or tortured during the military years (while neglecting those who suffered the same fate before and after the régime, as did most travestis and trans people), but by literary representations that follow the small lives of queer folks in their everyday routines and complicities.

Another issue raised by Abelove's students was the concept of agency and the agents present in "Gay \& Lesbian History": a narrative built around an individual agent, with a stable, coherent identity which at the end of the struggle can be fully expressed. This point is strongly related to what several philosophers of history have come to call "the end of Great Stories" (BERKHOFER 1995; JENKINS 1997), which has affected our way of understanding agency, temporality, identity and - of course - the historiographical profession. History as a "Great Story" tended to think of historical narratives as tales about the "coming of age" of an identity - for example, how gay/lesbian identities have "evolved" throughout history up until our days, when they would allegedly be more "authentic" and freer than in the past.

Queer historiography as those students understood it, on the contrary, would much rather have collective, perhaps anonymous, agents and, in particular, agents who maintain their contradictions and do not aim at achieving one singular, coherent and clear identity. As Stuart Hall has explained regarding "blackness", these identities have never just "been there" - they are "a narrative, a story, a history", and they are "constructed, told, spoken, not simply found" (quoted in SCOTT 1991, p. 792). "Normal" historiography (and perhaps historiography per se, but this should no doubt be studied further) needs to iron out differences and contradictions, as it tends to work with the idea of a common experience based on identities. The representations we are looking at here, on the other hand, as they follow the stories of small characters in their everyday lives, convey the idea not of a fixed identity but of a multiplicity of them, a complex "net" of 
identities that affect us. Queer stories can not only handle, but also value these contradictions, instabilities and incoherences present in their subjects. Characters in narrations, just like ourselves in everyday life, are made of a multiple array of identities, such as gender, class, ethnic background and political standing, among others. They are allowed to shift identities according to their situations, interactions or interests, and are not forced to be the "pure" representatives of any given community. Also, whereas the Great Stories (including the more recent contributions on behalf of "Gay \& Lesbian" historians) conveyed a rational, linear and individual agency, queer representations, including our more or less fictional accounts, prefer to emphasize everyday performative shifts and resistances.

As we saw in the beginning of this article, Valeria Ramírez eventually realized that her mere gender appearance could already be read as an act of resistance and political struggle, even though she did not have "a Che Guevara t-shirt" - in other words, even though she did not participate in institutional or insurrectional politics (RAMÍREZ 2011). In El diablo en el pelo, Roberto Echavarren makes sure his characters (and their genders and sexualities) are as confusing as possible, for instance by playing with their names: we are never too sure of how they are called, what the gender of their names is or who they are, as Julián can also be Lolito, Lola, Julia, Juliette; the first words he says are "no soy una mina" ("I am not a chick"), then he appears in a dream sitting at a doctor's office, pregnant; he refuses to be penetrated by his partner; he is regularly approached by men who feel attracted to him thinking he is a girl, and

212 he rejects them; then he tries to get his partner jealous by confessing that he regularly sleeps with older women. Malva, in her autobiography Mi Recordatorio, regularly shifts genders, calling herself alternatively in feminine and masculine terms, sometimes referring to herself as "mariquita" ("sissy"), other times as "maricón" ("fag"), "diferente sexual" ("sexually different"), "travesti" and others still as "homosexual".

These resources allow their authors and characters to sustain their sex/ gender "confusion", and to understand "confusion" not as something that has to be solved, but as part of being human.

Another feature privileged by queer readers, according to Abelove's research, were those representations of the past that did not use the nationState as a framework for their research, as this would imply naturalizing both this identity and its exclusions. If nationality had to appear in these narratives, it should be not as a given, but as an object of inquiry: how were these identities forged? What did they exclude? What exactly did it mean to be inside - or outside - them?

Queer approaches allow us to face our characters and their stories at the crossroads of their many identities or affiliations: sexual, gender, political, social, racial. Due to the complexity and even self-contradictory nature that these narratives allow for our characters, we can see them as they juggle with all these identities, without seeking a resolution in favor of any of them. We can even see them as different identities interact: in El diablo en el pelo, a white, rich man from Montevideo meets a marginal young kid from the outskirts of 
town, who lives on petty crimes and has never managed to finish school. In La brasa en la mano, different situations gather marines and soldiers, a "discrete" homosexual young man, an outlandish pansy and an elder woman who enjoys her sexuality with men from all classes, ages and origins. All of them carry with them a number of identities: the soldier feels somewhat "at home" when he goes into a bar with his occasional boyfriend and chats with a group of men just like himself, who spend their days sitting in the corner coming on to girls who wait for the bus. One sublime example of this meeting of identities is a novel I am not considering here: Manuel Puig's El beso de la mujer araña (Kiss of the Spider Woman) (1976). In this piece, probably the most important representation of homosexuality in Argentine literature, a prison cell unites a "sexual deviant" with a "political deviant" - one imprisoned due to his sexuality and gender presentation, and the other due to his political activity.

A particularly interesting line of research offered by queer historiographies is the issue of temporality and spatiality in these alternative representations. "Normal historiography" works in the realm of linear, limited space and time; it observes mainly public space, and is marked by the rhythm of official, mainstream temporality (which determines such varied issues as which years are important in the history of any given group, how much time is considered appropriate for the development of an event, etc.), and is usually engraved with an idea of progress. As we saw above, this temporality is often foreign to the lives of queer and marginal people, who experience different landmarks, paces and turning points in their (hi)stories. Our artistic representations of the past manage to convey an idea of this alternative temporality, absent from mainstream representations. As an example, if we analyze the cases at hand we will find repeatedly what Argentine writer and essayist Néstor Perlongher has called "the homosexual wandering" ("la deriva homosexual"): the erratic, almost nomadic drift of sexual and gender "deviants" through urban space. Queer geography and temporality are in many ways different from "normal" - again, in its Kuhnian sense - time and space. Perlongher speaks of "a whole mass that turns nomadic and regains an ancient, archaic use of the street" (1993, p. 76); ${ }^{6}$ this wandering through space, in a temporality that seems parallel to the mainstream clock, is one - if not the - main trope in the books I bring to consideration here. Urban and rural geographies are lived in a parallel time, in complicity with other queers and outcast characters (prostitutes; poor, nomadic artisans; homeless people, and so on), coinciding only incidentally with "normal" space and time - usually, when the forces of State repression make their appearance (such as the case of El beso de la Mujer Araña quoted above). Sometimes a trip to the beach seems to insert us again in society, but this is only illusory: long walks far from bathers, or scornful detachment from "common people" and their petty routines, immediately come to interrupt the illusion of normality.

The mere fact that we are looking into literary works for our representation of the past can be an interesting pointer towards the queerization of historiography.

\footnotetext{
6 "Toda una masa que se nomadiza y recupera un uso antiguo, arcaico, de la calle" (PERLONGHER 1993, p. 76).
} 
As we saw before, "normal historiography", just like "normal science" for Kuhn, has among other tasks the negative function of excluding the attempts which do not comply with the professional standards of historical research. Just like any profession, it guarantees its endurance by setting its own rules and policing allegiance to them. The downside of this is that it obviously results in many exclusions, and as a result only few people can legitimately claim to be "doing historiography" in this strict sense. Thus, certain voices, aesthetic styles and political stances are rarely, if ever, represented in the profession. Many tendencies in contemporary historiography - not necessarily related to queer thought have taken up the task of including other expressions of the past, such as films, books, theater plays, performing arts and other expressions. As Gilda Bevilacqua (2012, p. 193-194) has noticed specifically in relation to cinema, to the more traditional usages of artistic resources as representations of history (be it in terms of sources, or of means to represent what was previously established by historiography), we can add an alternative perspective, according to which both historiographical and non-historiographical approaches build meaning, and in particular historical meaning, standing therefore in a non-hierarchical relationship in terms of their potential to build knowledge about "the past". Be it as source, as means of representation, or as producers of historical meanings, the literary productions read here do not comply with the professional standards of "normal historiography", but do add other voices to the existing multi-choral narratives of the past. As we have seen in this paper, the inclusion of such resources (literary 214 ones, in this case) allow for a broadening of the view on the past, among other things regarding agency, subjects, identities and temporalities.

\section{Towards the multiplication of historiographies}

In this work, I have presented some reflections on the resources offered by literature for the representation of subjects and communities who inhabited the margins of the time and place researched. If I have brought forward the notion of "normal" or "mainstream" historiography, it has not been with the aim of proscribing such tendencies, or to suggest that they occupy a lesser position in some kind of evolutionary trajectory. My proposal is not to subtract or replace, but to include: various subjects, forms, contents and dynamics between one and the other. In this way, perhaps, the potential Milan Kundera has attributed to the novel can be extended to other expressions of the past:

[...] it is precisely in losing the certainty of truth and the unanimous agreement of others that man becomes an individual. The novel is the imaginary paradise of individuals. It is the territory where no one possesses the truth $[\ldots]$, but where everyone has the right to be understood (KUNDERA 2005, p. 159).

This is about broadening the view and thinking of other ways of representing the past: perhaps not in order to blend them with "normal historiography" (which, just like literature or any other genre, will still need some kind of exclusion for its survival), but to accompany it with other visions of the past. This broadening 
and dislocation of the possible representations of the past can serve as an open invitation to multiply its potential and build our way into a task that anyone and everyone should be able to do: queering historiography, and queering history, in order to build different presents and futures.

\section{Bibliographical references}

ABELOVE, Henry. The Queering of Lesbian/Gay History. Radical History Review, v. 62, p. 44-57, 1995.

ANKERSMIT, Frank. The Dilemma of Contemporary Anglo-Saxon Philosophy of History. History and Theory, v. 25, n. 4, 1986, p. 1-27.

BAZÁN, Osvaldo. Historia de la homosexualidad en la Argentina: de la conquista de América al siglo XXI. Buenos Aires: Marea, 2004.

BERKHOFER, Jr., Robert. Beyond the Great Story. Cambridge: Harvard University Press, 1995.

BEVILACQUA, Gilda. Del discurso 'histórico' al 'cinematográfico': Bastardos sin gloria y la construcción de la historia. In: NIGRA, F. (comp.). Visiones gratas del pasado. Buenos Aires: Imago Mundi, 2012, p. 193-209.

D'EMILIO, John, Sexual Politics, Sexual Communities: The Making of a Homosexual Minority in the United States 1940-1970. Chicago: University of Chicago Press, 1983.

DUBERMAN, Martin et al., Hidden from History: Reclaiming the Gay \& Lesbian Past. New York: New American Library, 1989.

HALBERSTAM, Jack. The Queer Art of Failure. Durham and London: Duke, 2011.

JENKINS, Keith. Introduction: On Being Open about Our Closures. In:

(Ed). The Postmodern History Reader. London and New York: Routledge, 1997. p. $1-30$.

KUHN, Thomas S. The Structure of Scientific Revolutions. Second Edition, Enlarged. International Encyclopedia of Unified Science, v. II, n. 2. Chicago: University of Chicago Press, 1970 [1962].

KUNDERA, Milan. The Art of the Novel. London: Faber and Faber, 2005 [1968].

LOVE, Heather. Feeling Backward. Loss and the Politics of Queer History. Cambridge and London: Harvard University Press, 2009.

MALVA. Mi recordatorio. Buenos Aires: Libros del Rojas, 2011.

PERLONGHER, Néstor. La prostitución masculina. Buenos Aires: De la Urraca, 1993.

RAMÍREZ, Valeria. Otros se ponían la camiseta del Che, nosotras teníamos los pechos [Others had a Che Guevara t-shirt, we had our breasts]. EI País, 27 enero 2011, Página 12. 
RAPISARDI, Flavio; MODARELLI, Alejandro. Fiestas, baños y exilios: los gays porteños en la última dictadura. Buenos Aires: Sudamericana, 2001.

RUSSO, Vito. The Celluloid Closet: Homosexuality in the Movies, Revised Edition. New York: Harper \& Row, 1987 [1981].

SCOTT, Joan W. The Evidence of Experience. Critical Inquiry, v. 17, n. 4, p. 773-797, 1991.

SPIVAK, Gayatri C. A Literary Representation of the Subaltern: A Woman's Text from the Third World. In Spivak (Ed.). Other Worlds: Essays in Cultural Politics. New York and London: Methuen, 1987.

WEEKS, Jeffrey. Coming Out: Homosexual Politics in Britain from the Nineteenth Century to the Present. London: Quartet, 1977.

WHITE, Hayden. El pasado práctico. In: TOZZI, V. ; LAVAGNINO, N. (eds.). Hayden White, la escritura del pasado y el futuro de la historiografía. Sáenz Peña: Universidad Nacional de Tres de Febrero, 2011, p. 19-39. 